\title{
South Africa endorses nonracial schools and increases subsidies
}

\begin{abstract}
Cape Town. The South African government has agreed to a single nonracial system of education as well as an increase in subsidies to universities for training more minority students in science and engineering.

Last month, the ruling National Party and the African National Congress (ANC) both releas $\mathrm{d}$ their new education policies. The ANC's "National Education Policy Investigation" is more vague than the "Education Renewal Strategy" (ERS) proposed by government, but all sides agree on the principle of one system.
\end{abstract}

The university subsidies are awarded according to a formula that takes into account undergraduate and postgraduate student numbers as well as their respective success rates. It also gives greater weight to those enrolled in the natural sciences, including science, engineering and medicine. But for the past five years the government has abandoned the formula, fixing subsidies at a straight percentage increase on the 1988 subsidy award, which reflects 1986 enrolment numbers.

The ERS recommends that the government revert immediately to the formula and provide 70 per cent of the subsidy due to the universities. This year, the government has given universities 65 per cent of their entitlement with the proviso that none should receive less in nominal terms than last year.

The restoration of the formula will redress differential rates of growth in the universities since 1986 . With inflation running at 10 per cent, a handful will receive a cut in real terms of a similar magnitude. But most of the established universities have grown modestly during the past five years and some, like the University of the Western
Cape and the University of the North, have doubled and tripled respectively in size. In addition, the formula has been modified by altering the weighting from 1.6:1 to $2.5: 1$ in favour of students in the natural sciences.

However, it is not as yet clear whether this will have the desired effect of increasing enrolment in these fields. The ANC document suggests a more radical solution: a centrally planned system in which the state would subsidize a fixed number of places in each field and then distribute them nationally.

A single education minister will be appointed by 1 April and given one year to integrate the existing racially constituted education departments into new regional executive departments. (There is at present one minister each for African, Coloured and Asian education plus Minister of National Education Piet Marais, who is responsible for both white education and policy coordination.) The ERS envisages three types of schools in the new dispensation: private schools (which nevertheless receive a large government subsidy), state-aided schools (for which the state pays salaries but not other expenses) and state schools (for which the state foots the entire bill).

The proportion of the total education budget allocated to postsecondary education has remained steady, with universities and technical schools getting a combined 15 per cent of the overall budget and teachertraining colleges receiving an additional 5 per cent. Although this year's spending figures will not be released until the budget is announced next month, Marais hinted at an increase in the overall education allocation during a press briefing last week.

Michael Cherry

\section{London meetings on British science}

On Friday 19 March, there will be a meeting at the Royal Society, 6 Carlton House Terrace, London SW1, to discuss proposals for the forthcoming White Paper on the organization of British science. The speakers will be Sir Eric Ash (Rector, Imperial College London), Professor Michael Brady (University of Oxford), Dr Dai Rees (Secretary, Medical Research Council) and Sir Mark Richmond (Chairman, Science and Engineering Research Council); the meeting will start at 9.30 a.m. and end at 4.00 p.m.

Admission to the meeting will be by ticket, free of charge, obtainable from Mary Sheehan, Nature, 4 Little Essex Street, London WC2R 3LF. Coffee and tea will be provided.

There will also be a sandwich lunch for those who want it, at a cost of $£ 5$ : please send a cheque made out to Nature with your ticket application. Tickets for both the meeting and lunch will be sent out during the second week of March.

* On Thursday 18 March, Save British Science is holding a meeting called "Waldegrave meets the scientists" at 12.30 p.m. in the Great Hall, Sherfield Building, Imperial College, London SW 7. The Rt Hon. William Waldegrave, MP, Chancellor of the Duchy of Lancaster and Minister of Public Service and Science, will speak and will answer questions. Entry free. Seats may be reserved by application to Save British Science, PO Box 241, Oxford OX1 3QQ (tel. 0865 273407, fax 511370).
NEWS IN BRIEF

Munich. Germany's new research minister, Matthias Wissmann, has won a battle for more money to strengthen research in eastern Germany. The government last week added DM50 million (US $\$ 30$ million) to an annual budget of DM330 million for applied research projects and promised to increase next year's budget by DM50 million. Industry has been promised an equal amount this year as part of a package to improve the flagging economy in the former East Germany.

Washington. Ashton Carter of Harvard University, a vocal critic of the original claim that the Strategic Defense Initiative (SDI) could protect the United States against an all-out Soviet attack, is expected to be put in charge of that and other programmes at the Defense Department. Carter joined many scientists in the mid-1980s in arguing that a directed-energy weapons system was not feasible. In recent years the debate has shifted to whether any type of SDI-type defence system is worth the cost (this year SDI will receive $\$ 3.5$ billion, and more than $\$ 20$ billion has been spent on it since 1983). Carter, as an assistant secretary of defence for policy, will also handle strategic issues such as nuclear nonproliferation and the dismantling of Soviet warheads.

J.M.

Munich. More than 5,000 biochemical researchers have signed a resolution calling on German scientists who have "friendly relationships and close personal contacts" with foreign colleagues to support and protect foreigners in Germany. "There is no place for discrimination and hatred as part of a peaceful Germany", the resolution states. Recent violent attacks on foreigners have raised questions about the wisdom of holding the IXth International Conference on AIDS in Berlin in June. But its chairman, KarlOtto Habermehl, says that a proposal to hold the congress outside Germany is unrealistic and not an answer to the problem. The attacks have not so far had a significant effect on applications, and some 15,000 people are expected to attend the meeting.

Munich \& London. Antonio Ruberti, the new research commissioner for the European Communities, is showing clear signs of respecting the advice of scientists. Since taking up his post in January, Ruberti has appointed as personal advisers two Nobel prizewinners - Belgian chemist llya Prigogine and Italian particle physicist Carlo Rubbia and French biologist François Gros, a former science adviser to the French president, François Mitterrand. Speaking last week at a symposium in Oxford on science and society, Ruberti said that he wanted "a closer relationship with the world of science" and to open up new areas of cooperation.

A.A. \& D.D. 